\title{
Anasınıfına devam eden çocuklara verilen drama eğitiminin çocukların zihinsel becerilerine etkisinin incelenmesi*
}

\author{
Investigation of the effect of drama education on preschool children's \\ mental ability
}

\author{
Elif Demir ${ }^{1}$, Fatma Elif Kllınç ${ }^{2}$
}

\author{
Makalale Geçmişi \\ Geliş : 25 Ocak 2018 \\ Düzeltme : 09 Mart 2018 \\ Kabul : 08 Nisan 2018 \\ Makale Türü \\ Özgün Makale
}

\begin{abstract}
Öz: Okul öncesi dönemde gelişim alanlarının birbiriyle ilişkisi oldukça fazladır ve çocuğun gelişiminin desteklenmesi büyük önem arz etmektedir. Zihin kuramının gelişimi bireyin sosyal ve bilişsel gelişiminin bir dönüm noktası olarak kabul edilmektedir. Zihin kuramı becerilerine ilişkin alan yazında bulunan çalışmaların oldukça sınırlı olduğu görülmektedir. Drama eğitimi ile zihin kuramı becerilerinin karşılaştırıldığı çalışmalar literatürde yok denecek kadar azdır. Bu çalışmada çocukların farklı bilgi ve beceriler edinmesine önemli katkıları bulunan drama eğitiminin çocukların zihinsel düşünme becerilerinin kazandırılmasına etkisini incelemek amaçlanmaktadır. Bu amacı gerçekleştirmek için deneysel yöntem kullanılmıştır. Araştırmada veri toplama aracı olarak araştırmacılar tarafından geliştirilen "Kişisel Bilgi Formu" ile anasınıfı çocuklarının zihinsel düşünme becerilerini ölçmek için Wellman ve Liu (2004) tarafından geliştirilen Gözün Kahraman (2012) tarafından Türkçe'ye uyarlanan Zihin Kuramı Ölçeği kullanılmıştır. Ölçek uygulayıcı tarafından çocuk ile yüz yüze uygulanarak ön test- son test- izleme testi olarak gerçekleştirilmiştir. Araştırmanın çalışma grubunu Ankara ili Çankaya ilçesinde okul öncesi eğitim kurumuna devam eden 15 deney, 15 kontrol grubuna dahil olan toplam 30 çocuk oluşturmaktadır. Araştırmanın sonucunda drama eğitimi alan çocuklarda zihin kuramı becerilerini ölçen beş alt boyutta anlamlı farklılaşma belirlenmiştir. Bu durum verilen drama eğitiminin anasınıfına devam eden çocukların zihinsel becerileri üzerinde olumlu etkiye sahip olduğunu göstermektedir.
\end{abstract}

Anahtar Kelimeler: Zihin kuramı, Zihinsel beceri, Drama, Çocuk

Abstract: Preschool period is called critical years regarding development. Cognitive development is closely related with other developmental areas. Studies on the theory of mind skills appears to be quite limited. The studies in which, the theory of drama and the mind theory skills are compared, are rarely found in the literature. For this reason, it is aimed to investigate the effect of drama education in the children's mental thinking skills. Experimental method has been used to realize this purpose. The "Personal Information Form" developed by the researchers as a means of data collection and the Mind Theory Scale adapted to Turkish by Gözün Kahraman (2012) developed by Wellman and Liu (2004) were used in the research to measure the mental thinking skills of the kindergarten children. The scale was applied face-to-face to child by the practitioner and performed as pre-test, post-test, follow-up test. The study group consisted of a total of 30 children, including 15 experimental groups and 15 control groups, who continued to the pre-school education institution in the province of Ankara, Çankaya. As a result of measuring mind theory skills among children which get drama education, significant differences were determined in five sub-dimensions positively.

Keywords: Mind Theory, Mental Skill, Drama, Child 


\section{SUMMARY}

\section{Introduction}

Developmental traits that are rapid in early childhood, though they slow down with the years ahead, continue throughout their lifetime. During this lifelong progression, there are critical periods that are more impacted by the environment and affect individual development. Early childhood is also among these periods. The development of all areas of the child who has had positive experiences during this period shows a positive progress (Schlinger, 2009; Santrock, 2011).

Mental theory, including the mental process, implies that the individual is able to understand, explain and be aware of the feelings, thoughts, point of view, intentions, situations in which are involved (Wellman ve Bartsch, 1994; Flavell ve Miller, 1998). Many countries have included creative thinking education and creative drama work in preschool education programs in order to develop thinking skills (Keskin, 2009). The Pre-School Education Program, which is implemented in all pre-primary education institutions in our country since 2013, reveals the importance of skills that improve children's creative thinking such as problem solving skills, reasoning and creative drama (MEB, 2013).

This study examines the effects of creative drama work on the acquisition of mental thinking skills on children who continue to the general purpose nursery. The study was conducted with children who continued to nursery classes due to their "theories of mind" develop ages are 4-5-6 years. In line with this general objective, the theory of creative drama, the influence on the subconscious; not own belief, not own request, information access, open false belief and content false beliefs were investigated.

\section{Method}

This research is a semi-empirical study in which the effect of creative drama studies on the attainment of mental thinking skills to children who are attending to nursery classes is investigated. In experimental models, the main purpose is to determine the causal relationship between variables. Experimental models are an important research method in terms of the effect of independent variables on the dependent variable and the relationship between these (Karasar, 2014).

The study group is composed of 30 childeren in Serpil Sumer State Nursery School in Dikmen,Çankaya, the province of Ankara, which under the Ministry of National Education, in 2016-2017 academic year. There are 15 children in the experimental group and 15 children in the control group. Total of 13 girls and 17 boys were included, 5 girls and 10 boys in experimental group and 8 girls and 7 boys in the control group. The study was completed without any loss of children. Children who are not mentally or physically disabled, live with their parents and have similar social conditions, are participating in the research.

It was determined before analysis that normal distributed data was not observed. For this reason, nonparametric tests were preferred in the analysis of data. Mental theoretical tasks of the experiment 
and control group were Mann Whitney $U$ test because there were two unrelated groups to examine the difference between the mean of the pre-test, post-test and retention test point scores. The Wilcoxon signed rank test was used to test the difference in mean scores for the pretest and posttest scores separately for the experimental and control groups. SPSS 22 program was used in the analysis of the data.

\section{Results}

Creative drama studies cause differentiation in the total scores of the three subscales of children's mind theoretic scale; their unwillingness to access information, open misconceptions, and the theoretical score of the mind. At the same time, pre-test and post-test scores, and post-test and retention test scores differ significantly for the five sub-dimensions of the children's mental theory task in the experimental group (self-assertive, non-belief, information accessibility, false belief and content false belief). This difference shows that creative drama training applied to children is effective in the development of children's mental skills.

This study is important regarding it shows that the mental thinking skills of the children, who are attending the nursery classes, can be supported by the creative drama training program. This research also shows that the education given by applying creative drama studies has improved mental thinking skills. Theory of mind ability is crucial for successful social communication and interaction. It is known that creative drama studies have contributed to the socialization through the effect of learning by doing and living. In our country, the ability of theory of mind studies seems to be very limited. In order to contribute to the field by understanding the importance of mental thinking skills that are crucial for communication with the social environment in the development of pre-school children, there is a need for interdisciplinary studies especially in the field of education.

\section{Conclusion and Discussion}

As a result of research, creative drama training applied to children seems to be effective in the development of children's mental skills. This finding supports the conclusion that Suddendorf and Fletcher Flinn $(1997 ; 1999)$ have a meaningful relationship between creativity and theories of mind in their work. Dietrich (2004) noted that research on creativity and the theory of the mind will contribute to both areas.

It is seen that creative drama practices are effective to giving children the ability of "understand different desires" in their nursery classes children. From the age of 4, children are aware of the fact that others may have a false belief or idea about a subject (Santrock 2011, Perner, 1999). (Appleton and Reddy, 1996; Benson, 2007; Santrock, 2011; Perner, 1999) Training for children has enhanced the ability to understand different desires ( Appleton and Reddy,1996; Benson, 2007; Santrock, 2011; Perner, 1999). Creative drama study shows that the given education which "non-belief" sub-dimension is not effective. It is foreseen that the performance for this sub-dimension can be improved by ensuring the continuity 
of the education programs to be applied to children. Findings show that mental concepts may develop positively with the general education to be applied to children are included in the literature (Fisher and Happe, 2005; Guajardo and Watson, 2002; Ozonof and Miller; 1995; Swettenham, 1996).

It has been found that the given education, "information access" sub-dimension of the theoretical scale, is effective in gaining mental thinking ability. Astington and Edward (2010) found that the rate of development in the information access sub-dimension of mind theory in their work showed a positive awareness of children regarding having multiple siblings, playing symbolic games, talking about experiential experiences, and reading story books.

It is seen that the given education, "open false belief" sub-dimension of the mind theoretical scale, is seen to be effective regarding mental thinking skills to creative drama studies. It is stated in the literature that the beginning of the age of mind theory acquisition is 4 years old and a 6-year-old child must have the ability to understand open false beliefs. (Granti, 2004; Keçeli Kays1lı and Acarlar, 2011; Lohmann and Tomasello, 2003; Santrock 2011). 


\section{GíRIȘ}

İlk çocuklukta hızlı olan gelişimsel özellikler ilerleyen yıllarla birlikte yavaşlasa dahi durmaksızın yaşam boyu devam etmektedir. Yaşam boyu devam eden bu ilerleyiş sırasında çevrenin daha fazla etkisine maruz kalınan ve bireydeki gelişimi etkileyen kritik dönemler bulunmaktadır. Erken çocukluk dönemi de bu dönemler arasındadır. Bu dönemde olumlu yaşantılar geçiren çocuğun tüm alanlardaki gelişimi olumlu ilerleyiş göstermektedir (Schlinger, 2009; Santrock, 2011).

Sosyal hayatta kişiler duygu, inanç ve hedef gibi zihinsel durumları kavrama yoluyla, davranışlar hakkında değerlendirme yaparak fikir yürütebilmektedirler. 'Zihin Kuramı' olarak adlandırılan bu kavram zihinsel bir beceridir. Bu kavram ile sosyal yaşamda hareket gerektiren istek, duygu, inanç gibi birbiriyle ilişkilendirilebilir zihin durumları hakkında çıkarımda bulunulmaktadır (Wellman ve Estes, 1986). Zihin kuramına sahip olan birey kendinin ve çevresindekilerin zihin durumlarının yansıtabilmektedir. Bu bireyin, çevresindekilerin kendisi ile aynı zihne sahip olmadığını fark etmesi sonucunda kendi istek, inanç ve niyet gibi zihinsel durumlarını kavrayarak zihinsel olarak bunları sosyal çevresine yansıtabilme becerisi ile sağlanmaktadır (Baron-Cohen, 2000).

Zihin kuramı zihinsel süreci kapsayan, bireyin kendisinin ve bir başka kişinin duygularını, düşüncesini, bakış açısını, niyetlerini, içinde bulunduğu durumu anlayabilmesi, açıklayabilmesi ve bunun farkında olabilmesi anlamına gelmektedir (Wellman ve Bartsch, 1994; Flavell ve Miller, 1998). Premack ve Woodruff (1978) tarafindan ilk olarak ortaya atılan zihin kuramı, iki araştırmacının hayvanlar üzerinde yaptığı çalışma sonucunda şempanzelerin davranışlarını insanların zihinsel süreçlerine atıfta bulunarak şekillendirdiğini ortaya koymuştur (Ertuğrul, 2011). Bunu da bir kurama bağlayarak, zihinsel süreçlerin gözlemlenebilir olmadığını fakat davranışların gözlenerek zihinsel süreçlerle açıklanabileceğini bulmuşlardır (Perner, 1999; Premack ve Woodruff, 1978).

Bebeklik yıllarında görünmeye başlanan sezgisel sosyal biliş aşamalı olarak gelişerek okul öncesinde üst seviye yansıtıcı sosyal biliş olarak gelişim göstermektedir. Zihin kuramı gelişimi bireyin kendisinin farkında olmasını sağlayarak, çevresini anlamasını ve gözlemlemesini sağlamaktadır (Suddendorf ve Fetcher Flinn, 1997; Perner, 1999). Zihin kuramı kişinin yalnız kendisini düşünmesinden ziyade, diğerlerinin de düşünceleri hakkında fikir yürütebilme becerisidir (Premack ve Woodruff, 1978). 
Büyüme ile birlikte beyin gelişimi hızlanan çocukta düşünme becerileri de gelişim göstermektedir. Düşünme becerileri yaşantılar yoluyla çevresi, kedisi ve diğerleri hakkında bilgi sahibi olan çocuğun zihnindeki zihinsel durumları işlemesidir. Çocuk ilerleyen yılllar ve edindiği deneyimler ve yaşantılar sonucu kazandığı düşünsel yetiler ile kendinden farklı kişiler hakkında çıkarımda bulunarak zihin kuramındaki üst düzey düşünme becerilerine ulaşmaktadır (Baron-Cohen, Leslie and Frith, 1985; Palut, 2006).

Erken çocukluk döneminde ortaya çıkan yeteneklerden biri olan yaratıcılık doğuştan gelerek her çocukta farklı seviyede görülmektedir. Erken yaşlarda verilen yaratıcılığı geliştiren aktiviteleri içeren eğitimler gelişimlerini olumlu yönden desteklemektedir (Dağlıoğlu, 2011). Yaratıcı düşünme geliştirilmeye elverişli bir beceridir. Yaratıcılık üst düzey düşünme yetisi gerektirmesi yönüyle zihin kuramında ve bu kuramdaki uygulamalarda yer alan düşünme becerilerindeki gelişimde de önemli rol oynamaktadır (Leslie, 1987; Suddendorf ve Fletcher Flinn, 1997; Aslan, 2001; Palut, 2006).

Bir sanat eğitimi, öğretim yöntemi ve disiplin olarak da nitelendirilen yaratıcı drama, oyuncuların kendilerini ve çevresindeki oyuncuları fark etmesi, keşfetmesi ve aynı zamanda empati becerilerini "belirli kurallar içinde özgürlük” sistemini kullanılarak üretme sürecine dönüştürülebilmektedir (Üstündağ, 1994). Literatürde farklı isimlendirmelerle karşımıza çıkan eğitici drama, yaratıcı drama, eğitsel drama ve eğitimde drama kavramları içeriksel yönden tamamen aynı kavramlar olmakla birlikte bu kavramların uluslararası literatürde, "Creative drama", "Drama in Education" ve "Educational Drama" olarak da adlandırıldığı bilinmektedir. Bu kavramlar, Türkçede genellikle "eğitici drama” olarak karşımıza çıkmaktadır. "Eğitici drama" terimindeki "eğitici” kavramı, "eğitilebilir" ve "eğitim ile ilgili” yönleri ön plana çıkarmaktadır. Drama içinde kullanılan herhangi bir düşünce ya da amaç içermesi ve farklı yöntemlerden faydalanılmasıyla, grupların deneyimleri sonucu ortaya çıkan canlandırmalara dayanmaktadır. Drama çalışmaları, drama lideri/eğitmeni ya da alanda yöntem olarak dramayı kullanan öğretmenlerin yönlendirmesiyle daha öncesinden hedeflenen amaçlar temel alınarak uygun bir ortamda deneyimlenmektedir ( Sağlam, 2003; Adıgüzel, 2012).

Çocuklarda düşünme becerilerinin geliştirilmesi amacıyla birçok ülke okul öncesi eğitim programlarında yaratıcı düşünme eğitimine ve yaratıcı drama çalışmalarına yer vermektedir (Keskin, 2009). 2013'den itibaren ülkemizde yer alan tüm okul öncesi eğitim kurumlarınca uygulanan Okul Öncesi Eğitim Programı ile çocuklardaki yaratıcı düşünce, problem çözme becerisi, akıl yürütme, yaratıcı drama gibi düşünmeyi geliştiren becerilerin önemi ortaya konmaktadir (MEB, 2013). 
Drama ve dramatik etkinlikler, çocukların sosyal, psiko-motor, bilişsel, duyuşşsal ve dil alanlarındaki gelişimlerini destekleyerek yaratıcı dramayla bir arada uygulandığında çocuğa farklı alanlarda yarar sağlamaktadır. Bu çalışma ile yukarıda açıklanan bilgiler doğrultusunda, zihin kuramındaki; istek, inanç, duygu, bilgiye erişim, yanlış inanç alt boyutlarına dayalı hazırlanan yaratıcı drama eğitim programının, çocuklara zihinsel düşünme becerileri kazandırmadaki etkisi incelenmiştir.

\section{YÖNTEM}

$\mathrm{Bu}$ araştırma, anasınıfına devam eden çocuklara zihinsel düşünme becerilerinin kazandırılmasında yaratıcı drama çalışmalarının etkisinin araştırıldığı yarı deneysel bir çalışmadır. Deneysel modellerde asıl amaç, değişkenler arasındaki neden sonuç ilişkisini belirlemektir. Deneysel modeller, bağımsız değişkende oluşan düzenli değişimlerin bağımlı değişken üzerine etkisi ve bu değişkenler arasında oluşan ilişkiyi göstermesi açısından önemli bir araştırma yöntemidir (Karasar, 2014).

\section{Çalışma Grubu}

Araştırmanın çalışma grubunu, 2016-2017 öğretim yılında Ankara ili Çankaya ilçesi sınırlarında Dikmen' de yer alan Milli Eğitim Bakanlığı'na ve devlete bağlı olan Serpil Sümer Anaokulu' na devam eden 30 çocuk oluşturmaktadır. Deney grubunda 15 çocuk, kontrol grubunda da 15 çocuk bulunmaktadır. Deney grubunda 5 kız 10 erkek, kontrol grubunda 8 kız 7 erkek olmak üzere toplamda $13 \mathrm{kız}$ ve 17 erkek çocuk araştırma yer almaktadır. Çalışma çocukların herhangi birinden fire verilmeden tamamlanmıştır. Araştırmaya, herhangi bir zihinsel ya da bedensel engeli bulunmayan, benzer sosyal yaşam koşullarına sahip olan ebeveynleri ile birlikte yaşayan çocuklar katılmıştır.

\section{Çalışmanın yapıldı̆̆ı ortam ve zaman}

Araştırma Şubat 2017 ile Mayıs 2017 tarihleri arasında 12 haftalık ön test- deneysel işlem- son test uygulamaları ve 4 haftalık aranın ardından Haziran 2017 tarihinde deney grubuna uygulanan izleme testi ile tamamlanmıştır. Yaratıcı drama içerisinde yer alan oyunları oynayarak zihinsel düşünme becerilerine dayalı eğitim planı uygulaması yapılırken çocukların oyunları tekrar tekrar oynamak istedikleri, eğlenceli zaman geçirdikleri gözlenmiştir. Uygulama yapılmadan önce sınıfın havalandırılmış ve aydınlık olmasına, ortada çocukların dikkatini dağıtabilecek materyallerin bulunmamasına dikkat edilerek rahat hareket edebilecekleri ortam oluşturulmuş, çalışma materyalleri önceden temin edilerek ve sınıfta hazır bulundurulmuştur. Deney ve kontrol gruplarına uygulanan ön test ve son testler kurumun 
görüşme odasında, çocukla birebir olacak şekilde, dikkat dağılmasını engellemek için sessiz bir ortamda 15- 20 dakikalık sürede uygulanmıştır.

\section{Veri Toplama Araçları}

Araştırmada veriler, araştırmacı tarafından geliştirilen Kişisel Bilgi Formu ve anasınıfı çocuklarının zihinsel düşünme becerilerini ölçmek için Zihin Kuramı Ölçeği (Wellman ve Liu, 2004) nin Özlem Gözün Kahraman (2011) tarafından yapılan “Zihin Kuramına Dayalı Eğitim Programının 48-60 Aylık Çocukların Bilişsel Bakış Açısı Becerileri Ve Prososyal Davranışları Üzerindeki Etkisinin İncelenmesi” adlı doktora tezinden, ölçeğin Türkçe' ye uyarlama çalışması aracılığı ile toplanmıştır. Çalışmada kullanılan ölçeğin uygulama izni alınmıştır.

\section{Kişisel Bilgi Formu}

Çalışma öncesinde velilerle toplantı düzenlenerek, araştırmacı tarafından hazırlanan öğrenciler ve aileleriyle ilgili soruları içeren on soruluk kişisel bilgi formunun doldurulması istenecektir. $\mathrm{Bu}$ formda çocukların cinsiyeti, kardeş sayısı, kaçıncı çocuk olduğu, annelerinin yaşı, öğrenim durumu, meslek bilgisi ile babanın yaşı, öğrenim durumu ve meslek bilgisine ilişkin sorular yer almaktadir.

\section{Zihin kuramı ölçeği}

Wellman ve Liu (2004), oluşturdukları gelişimsel ölçekte zihni altı alt boyutta değerlendirerek, çocuklardaki istek, duygu, bilgi ve inançları anlama ve yorumlamalarını sağlayacak görevler belirlemişlerdir. Bu görevler; farklı istekler (insanların aynı şey karşısında farklı isteklere sahip olma durumları), farklı inançlar (insanların karşılaştıkları benzer durumlarla ilgili birbirinden farklı inançlara sahip olma durumları), bilgi-bilgisizlik (herhangi bir şey doğru olsa bile kişinin bu doğruyu bilmemesi durumu), yanlış inanç (herhangi bir şey doğru olsa bile kişinin farklı bir şeyin doğru olduğuna inanabilmesi durumu) ve gizlenen duyguyu belirlemedir (kişinin bir şey hissetse bile farklı bir şey gösterebilmesi durumu). Ölçekte yer alan görevler birbirine benzer farklı zihinsel boyutlara odaklanarak, zihinsel durumların gerçeğin tersini yansıtabileceği ve kişilere göre farklılık gösterebileceği istek, duygu, bilgi ve inanç durumlarını sınamaktadır. Okul öncesi çocuklar için hazırlanan ölçekte basitten başlayarak aşamalı olarak zorlaşan görevler aşağıdaki alt boyutlarda yer almaktadır;

1. Kendi İsteği olmayan

2. Kendi inancı olmayan

3. Bilgi erişimi

4. Belirgin yanlış-inanç 
5. İçerik yanlış inanç

6. Dış görünüş-gerçekte hissedilen olumsuz duygu ölçeği ön hazırlığ 1

7. D1ş görünüş-gerçekte hissedilen olumsuz duygu

\section{Verilerin Analizi}

Deney ve kontrol gruplarına uygulanan ön test, son test ve kalıc1lık testinden elde edilen verilerin normal dağılım gösterip göstermediğini incelemek için Kolmogorov-Smirnova ve Shapiro-Wilk testleri kullanılmıştır. Verilerin normal dağılım göstermediği saptanmıştır ve bu nedenle verilerin analizinde parametrik olmayan testler tercih edilmiştir. Deney ve kontrol grubunun zihin kuramı görevleri ön test, son test ve kalıcılık testi puan ortalamalarına ilişkin farklılığı incelemek için ilişkisiz iki grup olduğundan dolayı Mann Whitney U testi uygulanmıştır. Deney ve kontrol grubu için ayrı ayrı ön test ve son test puanları için puan ortalamalarına ilişkin farklılı̆̆ı test etmek için ilişkili gruplar olduğu için Wilcoxon işaretli sıralar testi kullanılmıştır. Verilerin analizinde SPSS 22 programı kullanılmıştır.

\section{BULGULAR}

Yaratıcı drama uygulaması öncesinde deney ve kontrol gruplarındaki çocukların kendi isteği olmayan, kendi inancı olmayan, bilgi erişimi, açık yanlış inanç ve içerik yanlış inanç olmak üzere zihin kuramı ölçeğindeki beş göreve ve zihin kuramı ölçeği toplam puanına ilişkin aldıkları puanların Mann Whitney U testi sonuçları Tablo 1'de gösterilmiştir.

Tablo 1. Deney ve Kontrol Gruplarının Zihin Kuramı Görevlerine Illişkin Ön Test Puan Ortalamalarının Mann Whitney U Testi Sonuçları

\begin{tabular}{|c|c|c|c|c|c|c|}
\hline Zihin Kuramı Görevleri & Grup & $\mathbf{n}$ & $\begin{array}{c}\text { Sıra } \\
\text { Ortalaması }\end{array}$ & Sira Toplamı & $\mathbf{U}$ & $\mathbf{p}$ \\
\hline \multirow{2}{*}{ Kendi İsteği Olmayan } & Deney & 15 & 13,50 & 202,50 & \multirow{2}{*}{82,50} & \multirow{2}{*}{0,150} \\
\hline & Kontrol & 15 & 17,50 & 262,50 & & \\
\hline \multirow{2}{*}{ Kendi İnancı Olmayan } & Deney & 15 & 16,00 & 240,00 & \multirow{2}{*}{105,00} & \multirow{2}{*}{0,710} \\
\hline & Kontrol & 15 & 15,00 & 225,00 & & \\
\hline \multirow{2}{*}{ Bilgi Erişimi } & Deney & 15 & 14,50 & 217,50 & \multirow{2}{*}{97,50} & \multirow{2}{*}{0,417} \\
\hline & Kontrol & 15 & 16,50 & 247,50 & & \\
\hline \multirow{2}{*}{ Açık Yanlış İnanç } & Deney & 15 & 12,50 & 187,50 & \multirow{2}{*}{67,50} & \multirow{2}{*}{$0,015^{*}$} \\
\hline & Kontrol & 15 & 18,50 & 277,50 & & \\
\hline \multirow{2}{*}{ İçerik Yanlış İnanç } & Deney & 15 & 16,00 & 240,00 & \multirow{2}{*}{105,00} & \multirow{2}{*}{0,710} \\
\hline & Kontrol & 15 & 15,00 & 225,00 & & \\
\hline \multirow{2}{*}{$\begin{array}{c}\text { Zihin Kuramı Ölçeği } \\
\text { Toplam Puan }\end{array}$} & Deney & 15 & 12,20 & 183,00 & \multirow{2}{*}{63,00} & \multirow{2}{*}{$0,031^{*}$} \\
\hline & Kontrol & 15 & 18,80 & 282,00 & & \\
\hline
\end{tabular}

Tablo 1 incelendiğinde yapılan Mann Whitney U testi sonuçlarına göre deney ve kontrol grubundaki çocukların Zihin kuramı ölçeği kendi isteği olmayan $(U=82,50 ; p>0,05)$, kendi inancı olmayan ( $U=105,00 ; p>0,05)$, bilgi erişimi $(U=97,50 ; p>0,05)$ ve içerik yanlış inanç 
$(\mathrm{U}=105,00 ; \mathrm{p}>0,05)$ alt boyutları puanlarına ilişkin ön test ortalamaları arasında anlamlı bir fark olmadığı görülmektedir. Açık yanlış inanç alt boyutu $(U=67,50 ; p<0,05)$ ve zihin kuramı ölçeği toplam puanına $(U=63,00 ; p<0,05)$ ön test ortalamaları arasında anlamlı bir fark olduğu belirlenmiştir. $\mathrm{Bu}$ sonuç eğitime başlarken deney ve kontrol grubundaki çocukların zihin kuramı ölçeği; kendi isteği olmayan, kendi inancı olmayan, bilgi erişimi, içerik yanlış inanç alt boyutları yönünden benzer özelliklere sahip olduğunu göstermektedir. Açık yanlış inanç alt boyutu puanı ve zihin kuramı ölçeği toplam puanı açısından bakıldığında benzer özellikler göstermediği görülmektedir. Tablo incelendiğinde deney ve kontrol grubundaki çocukların aynı evrenden çekildiği söylenebilir.

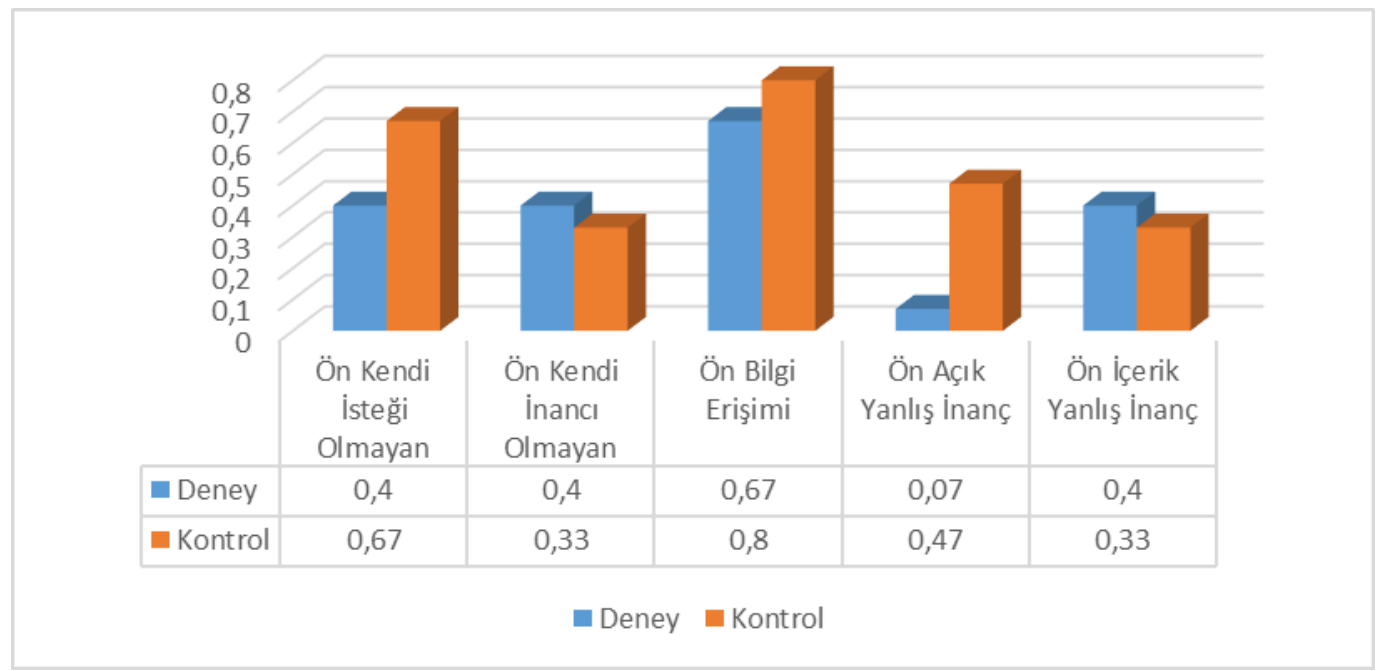

Grafik 1. Gruplara Göre Zihin Kuramı Görevleri Ön Test Puan Ortalamalarının Dağglımı

Deney ve kontrol gruplarının eğitim öncesindeki zihin kuramı ölçeğindeki açık yanlış inanç dışındaki tüm alt boyutlar için deney ve kontrol grubu ön test puanlarında anlamlı farklılık bulunamamıştır. Grafik 1'de bu sonuç görsel olarak gözükmektedir. Kendi isteği olmayan ve bilgi erişimi boyutları için kontrol grubunun ortalaması, kendi inancı olmayan ve içerik yanlış inancı için deney grubunun ölçekten aldıkları puanlar kısmen yüksek olsa da istatistiksel olarak bu fark anlamlı değildir.

Yaratıcı drama uygulaması sonrasında deney ve kontrol gruplarındaki çocukların kendi isteği olmayan, kendi inancı olmayan, bilgi erişimi, açık yanlış inanç ve içerik yanlış inanç olmak üzere zihin kuramı ölçeğindeki beş göreve ve zihin kuramı ölçeği toplam puanına ilişkin aldıkları puanların Mann Whitney U testi sonuçları Tablo 2'de gösterilmiştir. 
Tablo 2. Deney ve Kontrol Gruplarının Zihin Kuramı Görevlerine Illişkin Son Test Puan Ortalamalarının Mann Whitney U Testi Sonuçları

\begin{tabular}{|c|c|c|c|c|c|c|}
\hline Zihin Kuramı Görevleri & Grup & $\mathbf{n}$ & $\begin{array}{c}\text { Sira } \\
\text { Ortalaması } \\
\end{array}$ & Sira Toplamı & $\mathbf{U}$ & $\mathbf{p}$ \\
\hline \multirow{2}{*}{ Kendi İsteği Olmayan } & Deney & 15 & 19,50 & 292,50 & \multirow{2}{*}{52,50} & \multirow{2}{*}{$0,001 *$} \\
\hline & Kontrol & 15 & 11,50 & 172,50 & & \\
\hline \multirow{2}{*}{ Kendi İnancı Olmayan } & Deney & 15 & 17,00 & 255,00 & \multirow{2}{*}{90,00} & \multirow{2}{*}{0,203} \\
\hline & Kontrol & 15 & 14,00 & 210,00 & & \\
\hline \multirow{2}{*}{ Bilgi Erişimi } & Deney & 15 & 18,00 & 270,00 & \multirow{2}{*}{75,00} & \multirow{2}{*}{$0,016^{*}$} \\
\hline & Kontrol & 15 & 13,00 & 195,00 & & \\
\hline \multirow{2}{*}{ Açık Yanlış İnanç } & Deney & 15 & 17,50 & 262,50 & \multirow{2}{*}{82,50} & \multirow{2}{*}{0,128} \\
\hline & Kontrol & 15 & 13,50 & 202,50 & & \\
\hline \multirow{2}{*}{ İçerik Yanlış İnanç } & Deney & 15 & 18,00 & 270,00 & \multirow{2}{*}{75,00} & \multirow{2}{*}{0,063} \\
\hline & Kontrol & 15 & 13,00 & 195,00 & & \\
\hline \multirow{2}{*}{$\begin{array}{c}\text { Zihin Kuramı Ölçeği } \\
\text { Toplam Puan }\end{array}$} & Deney & 15 & 20,70 & 310,50 & \multirow{2}{*}{34,50} & \multirow{2}{*}{$0,001 *$} \\
\hline & Kontrol & 15 & 10,30 & 154,50 & & \\
\hline
\end{tabular}

Tablo 2 incelendiğinde yapılan Mann Whitney $U$ testi sonuçlarına göre deney ve kontrol grubundaki çocukların Zihin kuramı ölçeği kendi inancı olmayan ( $U=90,00 ; p>0,05)$, açık yanlış inanç $(U=82,50 ; p>0,05)$ ve içerik yanlış inanç $(U=105,00 ; p>0,05)$ alt boyutları puanlarına ilişkin son test ortalamaları arasında anlamlı bir fark olmadığı görülmektedir. Ölçeğin kendi isteği olmayan ( $U=52,50 ; p<0,05)$, bilgi erişimi $(U=75,00 ; p<0,05)$ alt boyutları ve zihin kuramı ölçeği toplam puanı $(U=34,50 ; p<0,05)$ son test ortalamaları arasında anlamlı bir fark olduğu belirlenmiştir. Bu sonuç eğitim yapıldıktan sonra deney ve kontrol grubundaki çocukların zihin kuramı ölçeği kendi inancı olmayan, açık yanlış inanç ve içerik yanlış inanç alt boyutlarındaki özelliklerinin değişmediğini göstermektedir. Diğer yandan açık yanlış anlayış arasında ön test puanları arasında fark varken son test puanları arasında farklılı̆̆ın çıkmaması, yapılan eğitimin açık yanlış inanç yönünden iki grubu benzer hale getirdiği şeklinde ve açık yanlış inanç üzerinde de etkili olduğu şeklinde yorumlanabilir. Kendi isteği olmayan ve bilgi erişimi alt boyutları puanı açısından bakıldığında ise yapılan eğitimin bu boyutlarda farklılaşmaya neden olduğu diğer bir deyişle etkili olduğu söylenebilir. Sonuç olarak yaratıcı drama uygulamaları altı yaş grubu çocuklarının zihin kuramı ölçeğinin kendi isteği olmayan, bilgi erişimi ve açık yanlış inanç alt boyutlarının gelişiminde etkili olmuştur. 


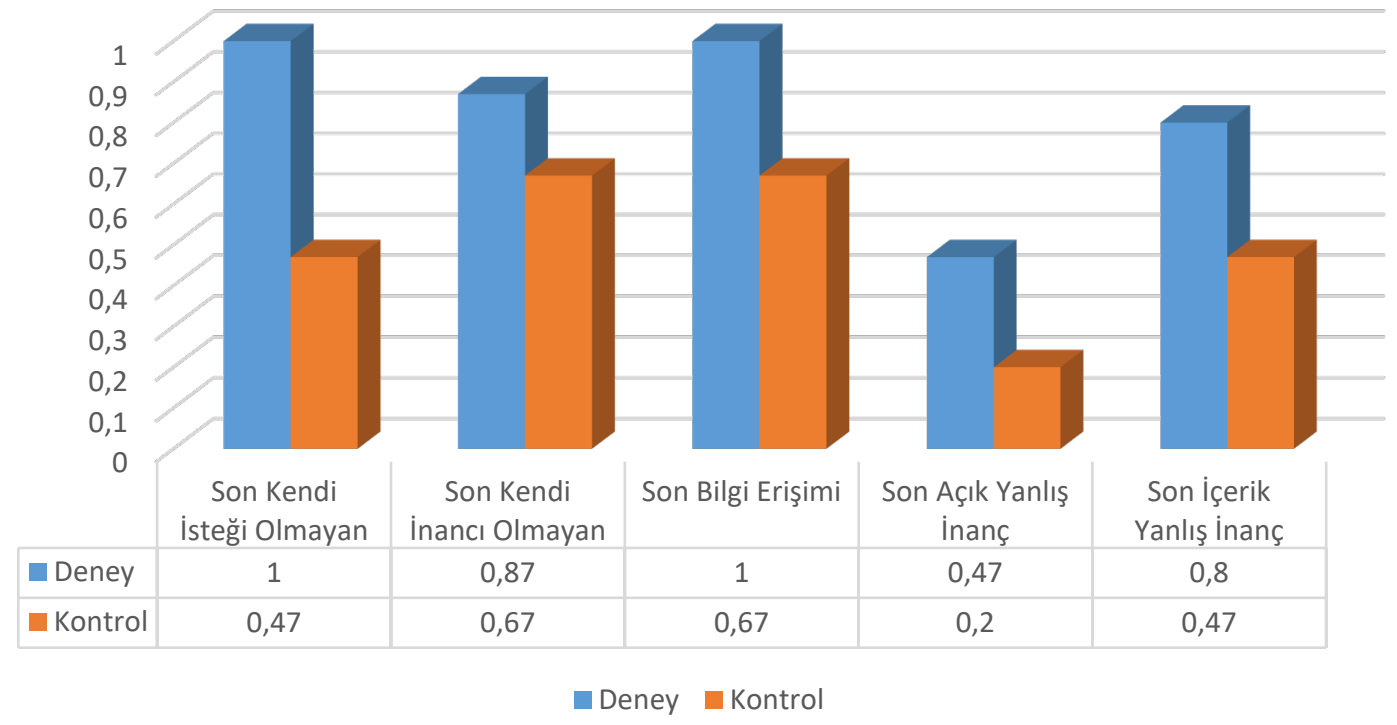

Grafik 2. Gruplara Göre Zihin Kuramı Görevleri Son Test Puan Ortalamalarının Dağılımı

Deney ve kontrol gruplarının eğitim sonrasındaki zihin kuramı ölçeğindeki kendi isteği olmayan ve bilgi erişimi dışındaki tüm alt boyutlar için deney ve kontrol grubu son test puanlarında anlamlı farklılık bulunamamıştır. Grafik 2'de bu sonuç görsel olarak gözükmektedir. Kendi isteği olmayan ve bilgi erişimi boyutları için kontrol grubu ortalaması deney grubu ortalaması arasındaki fark fazladır ve bu fark yapılan analiz sonucunda da istatistiksel olarak anlamlı bulunmuştur. Kendi inancı olmayan ve içerik yanlış inancı için deney grubunun ölçekten aldıkları puanlar kontrol grubuna göre kısmen yüksek olsa da istatistiksel olarak bu fark anlamlı bulunmamıştır. Açık anlayış inanç alt boyutu için deney ve kontrol grubu arasında fark anlamlı bulunmamıştır. Ancak açık yanlış inanç alt boyutu için Grafik 1'deki durum ile Grafik 2'deki durum karşılaştırıldığında, deney grubunun yapılan eğitimden sonra bir gelişme gösterdiği söylenebilir.

Deney grubundaki çocukların kendi isteği olmayan, kendi inancı olmayan, bilgi erişimi, açık yanlış inanç ve içerik yanlış inanç olmak üzere zihin kuramı ölçeğindeki beş göreve ilişkin ön test ve son test puanları arasındaki farkı incelemek için Wilcoxon İşaretli Sıralar Testi kullanılmıştır. Sonuçlar Tablo 3'de özetlenmiştir. 
Tablo 3. Deney Grubundaki Çocukların Zihin Kuramı Görevlerine İlişkin Ön Test ve Son Test Ortalamaları Arasındaki Farkın Incelenmesine Wilcoxon Işsaretli Sıralar İlişkin Testi Sonuçları

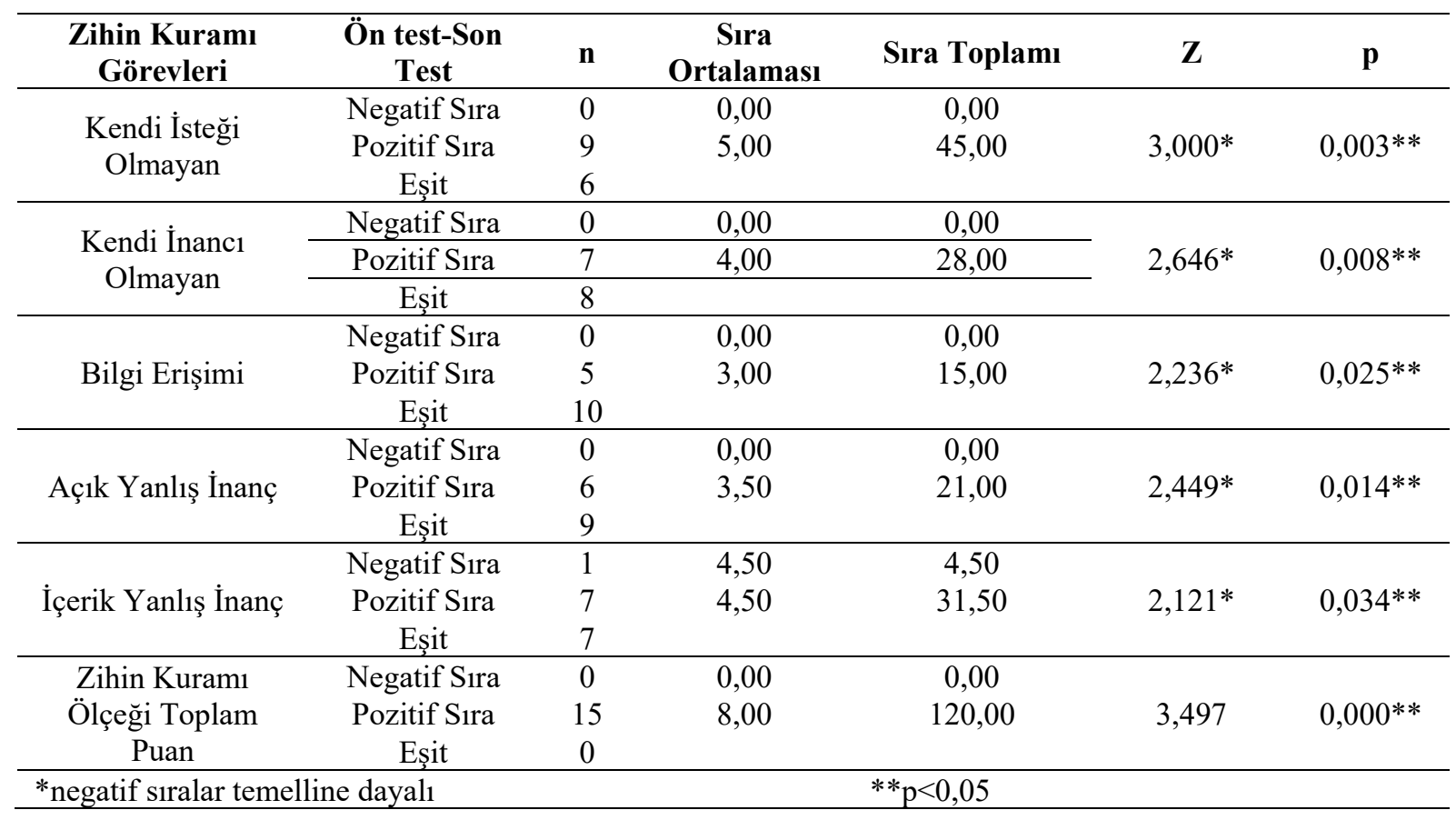

Tablo 3'e göre deney grubundaki çocukların kendi isteği olmayan $(Z=3,000 ; p<0,05)$, kendi inancı olmayan $(Z=2,646$; $p<0,05)$, bilgi erişimi $(Z=2,236$; $p<0,05)$, açık yanlış inanç $(Z=2,449$; $\mathrm{p}<0,05)$, içerik yanlış inanç $(Z=2,121 ; \mathrm{p}<0,05)$ olmak üzere zihin kuramı ölçeğindeki beş göreve ilişkin ve zihin kuramı ölçeği toplam puanı $(Z=3,497 ; p<0,05)$ ön test ve son test puanları arasında anlamlı bir fark olduğu görülmektedir. Fark puanlarının sıra ortalaması ve sıra toplamları dikkate alındığında, gözlenen bu farkın pozitif sıralar, yani son test puanı lehinde olduğu görülmektedir. $\mathrm{Bu}$ sonuçlara göre, yaratıcı drama uygulamasını zihin kuramı ölçeğindeki beş görevinde (çocukların kendi isteği olmayan, kendi inancı olmayan, bilgi erişimi, açık yanlış inanç ve içerik yanlış inanç) de etkili olduğu söylenebilir. 


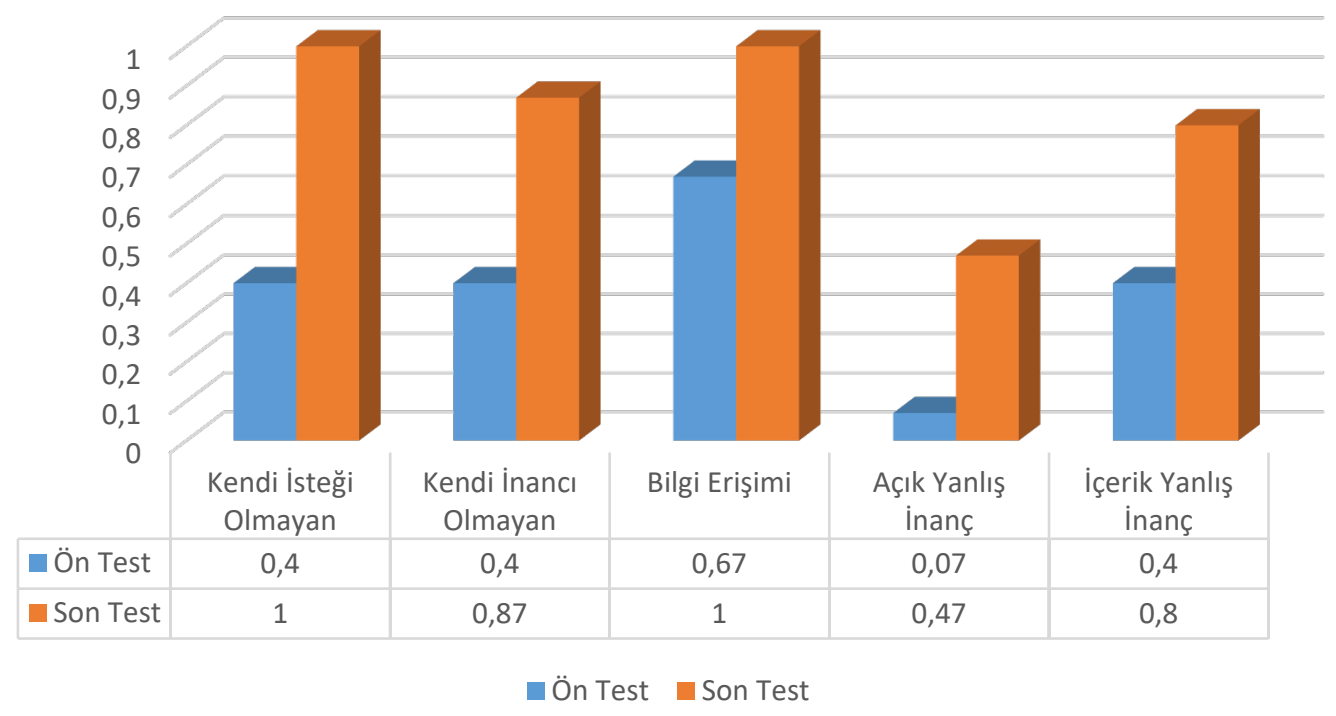

Grafik 3. Deney Grubundaki Çocukların Zihin Kuramı Görevlerine İlişkin Ön Test- Son Test Puan Ortalamalarının Dağılımları

Grafik 3 incelendiğinde deney grubundaki çocukların zihin kuramı görevinin beş alt boyutu için (kendi isteği olmayan, kendi inancı olmayan, bilgi erişimi, açık yanlış inanç ve içerik yanlış inanç) ön test ve son test puanları arasında oldukça fazla fark olduğu ve bu farkın her alt boyut için son test lehine olduğu görülmektedir. Yapılan analiz sonucunda aynı zamanda bu farklar anlamlı olarak farklı bulunmuştur. Bu durum yaratıcı drama uygulamasının çocukların zihin kuramı görevlerini yapmada etkili olduğu şeklinde yorumlanabilir.

Deney grubundaki çocukların kendi isteği olmayan, kendi inancı olmayan, bilgi erişimi, açık yanlış inanç ve içerik yanlış inanç olmak üzere zihin kuramı ölçeğindeki beş göreve ilişkin son test ve kalıcılık testi puanları arasındaki farkı incelemek için Wilcoxon İşaretli Sıralar Testi kullanılmıştır. Sonuçlar Tablo 4’te özetlenmiştir. 
Tablo 4. Deney Grubundaki Çocukların Zihin Kuramı Görevlerine İlişkin Ön Test ve Son Test Ortalamaları Arasındaki Farkın İncelenmesine Wilcoxon İ̧aretli Sıralar İlişkin Testi Sonuçları

\begin{tabular}{|c|c|c|c|c|c|c|}
\hline $\begin{array}{c}\text { Zihin Kuramı } \\
\text { Görevleri }\end{array}$ & $\begin{array}{c}\text { Ön test-Son } \\
\text { Test }\end{array}$ & $\mathbf{n}$ & $\begin{array}{c}\text { Sira } \\
\text { Ortalaması } \\
\end{array}$ & Sira Toplamı & $\mathbf{Z}$ & $\mathbf{p}$ \\
\hline \multirow{2}{*}{$\begin{array}{l}\text { Kendi İsteği } \\
\text { Olmayan }\end{array}$} & Negatif Sira & 3 & 2,00 & 6,00 & & \\
\hline & $\begin{array}{l}\text { Pozitif Sıra } \\
\text { Esit }\end{array}$ & $\begin{array}{c}0 \\
12\end{array}$ & 0,00 & 0,00 & $1,732 *$ & 0,083 \\
\hline \multirow[b]{2}{*}{$\begin{array}{l}\text { Kendi İnanc1 } \\
\text { Olmayan }\end{array}$} & Negatif Sira & 3 & 2,50 & 7,50 & & \\
\hline & $\begin{array}{l}\text { Pozitif Sıra } \\
\text { Eşit }\end{array}$ & $\begin{array}{c}1 \\
11\end{array}$ & 2,50 & 2,50 & $1,000^{*}$ & 0,317 \\
\hline \multirow[b]{2}{*}{ Bilgi Erişimi } & Negatif Sira & 0 & 0,00 & 0,00 & & \\
\hline & $\begin{array}{c}\text { Pozitif Sıra } \\
\text { Eşit }\end{array}$ & $\begin{array}{c}0 \\
15 \\
\end{array}$ & 0,00 & 0,00 & $0,000^{* *}$ & 1,000 \\
\hline \multirow[b]{2}{*}{ Açık Yanlış İnanç } & Negatif Sira & 3 & 4,50 & 13,50 & & \\
\hline & $\begin{array}{c}\text { Pozitif Sıra } \\
\text { Eşit }\end{array}$ & $\begin{array}{l}5 \\
7 \\
\end{array}$ & 4,50 & 22,50 & $0,707 * * *$ & 0,480 \\
\hline İçerik Yanlış İnanç & $\begin{array}{c}\text { Negatif Sıra } \\
\text { Pozitif Sıra } \\
\text { Eşit }\end{array}$ & $\begin{array}{c}0 \\
3 \\
12 \\
\end{array}$ & $\begin{array}{l}0,00 \\
2,00\end{array}$ & $\begin{array}{l}0,00 \\
6,00\end{array}$ & $1,732 * * *$ & 0,083 \\
\hline Zihin Kuramı & Negatif Sira & 6 & 5,50 & 33,00 & & \\
\hline $\begin{array}{l}\text { Ölçeği Toplam } \\
\text { Puan }\end{array}$ & $\begin{array}{l}\text { Pozitif Sıra } \\
\text { Esit }\end{array}$ & $\begin{array}{l}5 \\
4\end{array}$ & 6,60 & 33,00 & $0,087^{* *}$ & 0,931 \\
\hline $\begin{array}{l}\text { *pozitif siralar teme } \\
* * \text { negatif siralar ten }\end{array}$ & $\begin{array}{l}\text { dayal1 } \\
\text { e dayal1 }\end{array}$ & & & **pozitif ve neg & siralar tople & \\
\hline
\end{tabular}

Tablo 4'e göre deney grubundaki çocukların kendi isteği olmayan $(Z=1,732 ; p>0,05)$, kendi inancı olmayan $(Z=1,000 ; p>0,05)$, bilgi erişimi $(Z=0,000 ; p>0,05)$, açık yanlış inanç $(Z=0,707$; $\mathrm{p}>0,05)$ ve içerik yanlış inanç $(Z=1,732 ; p>0,05)$ olmak üzere zihin kuramı ölçeğindeki beş göreve ve zihin kuramı toplam puanına $(Z=0,087 ; p>0,05)$ ilişkin son test ve kalıcılık testi puanları arasında anlamlı bir fark olmadığı görülmektedir. Bu sonuçlara göre, yaratıcı drama uygulaması sonrasında zihin kuramı ölçeğindeki beş görevinden (çocukların kendi isteği olmayan, kendi inancı olmayan, bilgi erişimi, açık yanlış inanç ve içerik yanlış inanç) elde edilen gelişimin devam ettiği söylenebilir. 


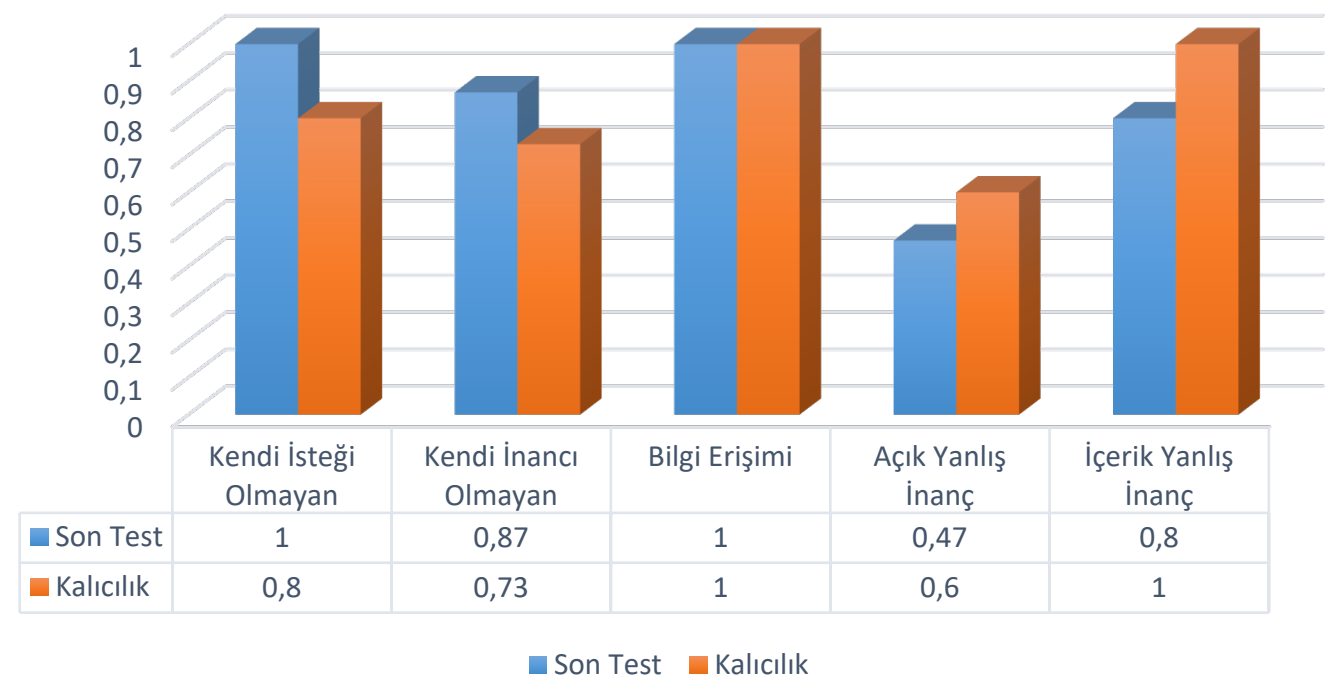

Grafik 4. Deney Grubundaki Çocukların Zihin Kuramı Görevlerine İiş̧kin Son Test ve Kalıcılık Test

\section{Puan Ortalamalarının Dağılımları}

Grafik 4 incelendiğinde deney grubundaki çocukların zihin kuramı görevinin beş alt boyutu için (kendi isteği olmayan, kendi inancı olmayan, bilgi erişimi, açık yanlış inanç ve içerik yanlış inanç) son test ve kalıcılık testi puanları arasında oldukça az fark olduğu görülmektedir. Yapılan analiz sonucunda aynı zamanda bu farklar anlamlı olarak farklı bulunmamıştır. Bu durum yaratıcı drama uygulaması sonucunda çocuklarda zihin kuramı görevlerinden elde edilen gelişimin kalıcı olduğunun bir göstergesi olduğu şeklinde yorumlanabilir.

Kontrol grubundaki çocukların kendi isteği olmayan, kendi inancı olmayan, bilgi erişimi, açık yanlış inanç ve içerik yanlış inanç olmak üzere zihin kuramı ölçeğindeki beş göreve ilişkin ön test ve son test puanları arasındaki farkı incelemek için Wilcoxon İşaretli Sıralar Testi kullanılmıştır. Sonuçlar Tablo 5'te özetlenmiştir. 
Tablo 5. Deney Grubundaki Çocukların Zihin Kuramı Görevlerine İlişkin Ön Test ve Son Test Ortalamaları Arasındaki Farkın Incelenmesine Wilcoxon Işsaretli Sıralar Iliş̧kin Testi Sonuçları

\begin{tabular}{|c|c|c|c|c|c|c|}
\hline $\begin{array}{c}\text { Zihin Kuramı } \\
\text { Görevleri }\end{array}$ & $\begin{array}{c}\text { Ön test-Son } \\
\text { Test }\end{array}$ & $\mathbf{n}$ & $\begin{array}{c}\text { Sira } \\
\text { Ortalaması }\end{array}$ & Sıra Toplamı & $\mathbf{Z}$ & $\mathbf{p}$ \\
\hline \multirow[b]{2}{*}{$\begin{array}{l}\text { Kendi İsteği } \\
\text { Olmayan }\end{array}$} & Negatif Sira & 4 & 3,00 & 12,00 & & \\
\hline & $\begin{array}{l}\text { Pozitif Sira } \\
\text { Esit }\end{array}$ & $\begin{array}{c}1 \\
10\end{array}$ & 3,00 & 3,00 & $1,342 * *$ & 0,180 \\
\hline \multirow[b]{2}{*}{$\begin{array}{l}\text { Kendi İnancı } \\
\text { Olmayan }\end{array}$} & Negatif Sira & 1 & 4,00 & 4,00 & & \\
\hline & $\begin{array}{l}\text { Pozitif Sıra } \\
\text { Eşit }\end{array}$ & $\begin{array}{l}6 \\
8 \\
\end{array}$ & 4,00 & 24,00 & $1,890^{*}$ & 0,059 \\
\hline \multirow[b]{2}{*}{ Bilgi Erişimi } & Negatif Sira & 4 & 3,50 & 14,00 & & \\
\hline & $\begin{array}{l}\text { Pozitif Sira } \\
\text { Eşit }\end{array}$ & $\begin{array}{l}2 \\
9\end{array}$ & 3,50 & 7,00 & $0,816^{* *}$ & 0,414 \\
\hline \multirow[b]{2}{*}{ Açık Yanlış İnanç } & Negatif Sira & 5 & 3,50 & 17,50 & & \\
\hline & $\begin{array}{l}\text { Pozitif Sira } \\
\text { Eşit }\end{array}$ & $\begin{array}{l}1 \\
9\end{array}$ & 3,50 & 3,50 & $1,633 * *$ & 0,102 \\
\hline \multirow[b]{2}{*}{ İçerik Yanlış İnanç } & Negatif Sira & 3 & 4,50 & 13,50 & & \\
\hline & $\begin{array}{l}\text { Pozitif Sira } \\
\text { Eşit }\end{array}$ & $\begin{array}{l}5 \\
7\end{array}$ & 4,50 & 22,50 & $0,707^{*}$ & 0,480 \\
\hline Zihin Kuramı & Negatif Sira & 5 & 6,30 & 31,50 & & \\
\hline Ölçeği Toplam & Pozitif Sıra & 5 & 4,70 & 23,50 & 0,418 & 0,676 \\
\hline Puan & Eşit & 5 & & & & \\
\hline \multicolumn{3}{|c|}{ *negatif sıralar temelline dayalı } & & **pozitif sırala & elline day & \\
\hline
\end{tabular}

Tablo 5'e göre kontrol grubundaki çocukların kendi isteği olmayan $(Z=1,342 ; p>0,05)$, kendi inancı olmayan $(Z=1,890 ; p>0,05)$, bilgi erişimi $(Z=0,816 ; p>0,05)$, açık yanlış inanç $(Z=1,633$; $p>0,05)$, içerik yanlış inanç $(Z=0,707 ; p>0,05)$ olmak üzere zihin kuramı ölçeğindeki beş göreve ve zihin kuramı ölçeği toplam puanı $(Z=0,418 ; p>0,05)$ ilişkin ön test ve son test puanları arasında anlamlı bir fark olmadığg görülmektedir.

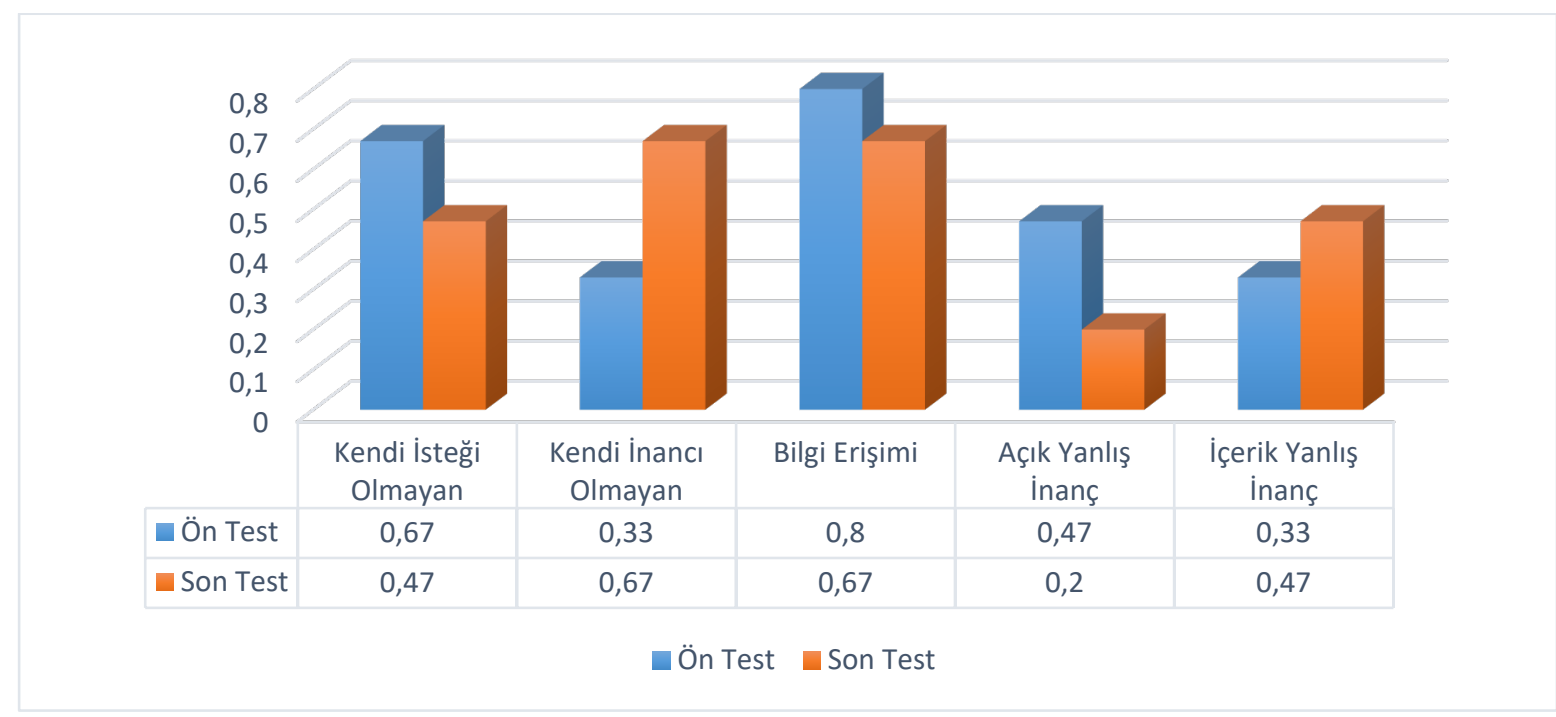

Grafik 5. Kontrol Grubundaki Çocukların Zihin Kuramı Görevlerine İlişkin Ön Test ve Son Test Puan Ortalamalarının Dağılımları 
Grafik 5 incelendiğinde kontrol grubundaki çocukların zihin kuramı görevinin beş alt boyutu için (kendi isteği olmayan, kendi inancı olmayan, bilgi erişimi, açık yanlış inanç ve içerik yanlış inanç) ön test ve son test puanları arasında oldukça az fark olduğu görülmektedir. Yapılan analiz sonucunda aynı zamanda bu farklar anlamlı olarak farklı bulunmamıștır. Bu durum kontrol grubundaki çocuklara yaratıcı drama uygulaması etkinlikleri uygulanmadığı için beklenen bir durumdur.

Yaratıcı drama uygulaması sonrasında ve öncesinde alınan puanların farkı (erişi puanları) bakımından deney ve kontrol gruplarındaki çocukların kendi isteği olmayan, kendi inancı olmayan, bilgi erişimi, açık yanlış inanç ve içerik yanlış inanç olmak üzere zihin kuramı ölçeğindeki beş göreve ve zihin kuramı ölçeği toplam puanına ilişkin aldıkları puanların Mann Whitney U testi sonuçları Tablo 6'da verilmiştir.

Tablo 6. Deney ve Kontrol Gruplarının Zihin Kuramı Görevleri Eriși Puan Ortalamalarının Mann Whitney U Testi Sonuçları

\begin{tabular}{|c|c|c|c|c|c|c|}
\hline Zihin Kuramı Görevleri & Grup & $\mathbf{n}$ & $\begin{array}{c}\text { Sira } \\
\text { Ortalaması }\end{array}$ & Sira Toplamı & $\mathbf{U}$ & $\mathbf{p}$ \\
\hline \multirow{2}{*}{ Kendi İsteği Olmayan } & Deney & 15 & 10,70 & 304,50 & \multirow{2}{*}{40,50} & \multirow{2}{*}{$0,001 *$} \\
\hline & Kontrol & 15 & 20,30 & 160,50 & & \\
\hline \multirow{2}{*}{ Kendi İnancı Olmayan } & Deney & 15 & 14,73 & 244,00 & \multirow{2}{*}{101,00} & \multirow{2}{*}{0,586} \\
\hline & Kontrol & 15 & 16,27 & 221,00 & & \\
\hline \multirow{2}{*}{ Bilgi Erişimi } & Deney & 15 & 12,67 & 275,00 & \multirow{2}{*}{70,00} & \multirow{2}{*}{$0,039 *$} \\
\hline & Kontrol & 15 & 18,33 & 190,00 & & \\
\hline \multirow{2}{*}{ Açık Yanlış İnanç } & Deney & 15 & 11,50 & 292,50 & \multirow{2}{*}{52,50} & \multirow{2}{*}{$0,005^{*}$} \\
\hline & Kontrol & 15 & 19,50 & 172,50 & & \\
\hline \multirow{2}{*}{ İçerik Yanlış İnanç } & Deney & 15 & 14,03 & 254,50 & \multirow{2}{*}{90,50} & \multirow{2}{*}{0,317} \\
\hline & Kontrol & 15 & 16,9 & 210,50 & & \\
\hline \multirow{2}{*}{$\begin{array}{c}\text { Zihin Kuramı Ölçeği } \\
\text { Toplam Puan }\end{array}$} & Deney & 15 & 21,90 & 328,50 & \multirow{2}{*}{16,50} & \multirow{2}{*}{$0,000^{*}$} \\
\hline & Kontrol & 15 & 9,10 & 136,50 & & \\
\hline$* \mathrm{p}<0,05$ & & & & & & \\
\hline
\end{tabular}

Tablo 6 incelendiğinde yapılan Mann Whitney U testi sonuçlarına göre deney ve kontrol grubundaki çocukların Zihin kuramı ölçeği kendi inancı olmayan ( $U=101,00 ; p>0,05)$ ve içerik yanlış inanç $(U=90,50 ; p>0,05)$ alt boyutları puanlarına ilişkin erişi puanları ortalamaları arasında anlamlı bir fark olmadığı görülmektedir. Ölçeğin kendi isteği olmayan $(U=40,50 ; p<0$, 05), bilgi erişimi ( $U=70,00 ; p<0,05)$, açık yanlış inanç $(U=52,50 ; p<0,05)$ alt boyutları ve zihin kuramı ölçeği toplam puanı $(U=16,50 ; p<0,05)$ son test ortalamaları arasında anlamlı bir fark olduğu belirlenmiştir. Bu sonuç eğitim yapıldıktan sonra deney ve kontrol grubundaki çocukların zihin kuramı ölçeği kendi inancı olmayan ve içerik yanlış inanç alt boyutlarındaki özelliklerinin değişmediğini göstermektedir. Kendi isteği olmayan, bilgi erişimi, açık yanlış inanç alt boyutları zihin kuramı ölçeği toplam puanı açısından bakıldığında ise yapılan eğitimin farklılaşmaya neden olduğu diğer bir deyişle etkili olduğu söylenebilir. 


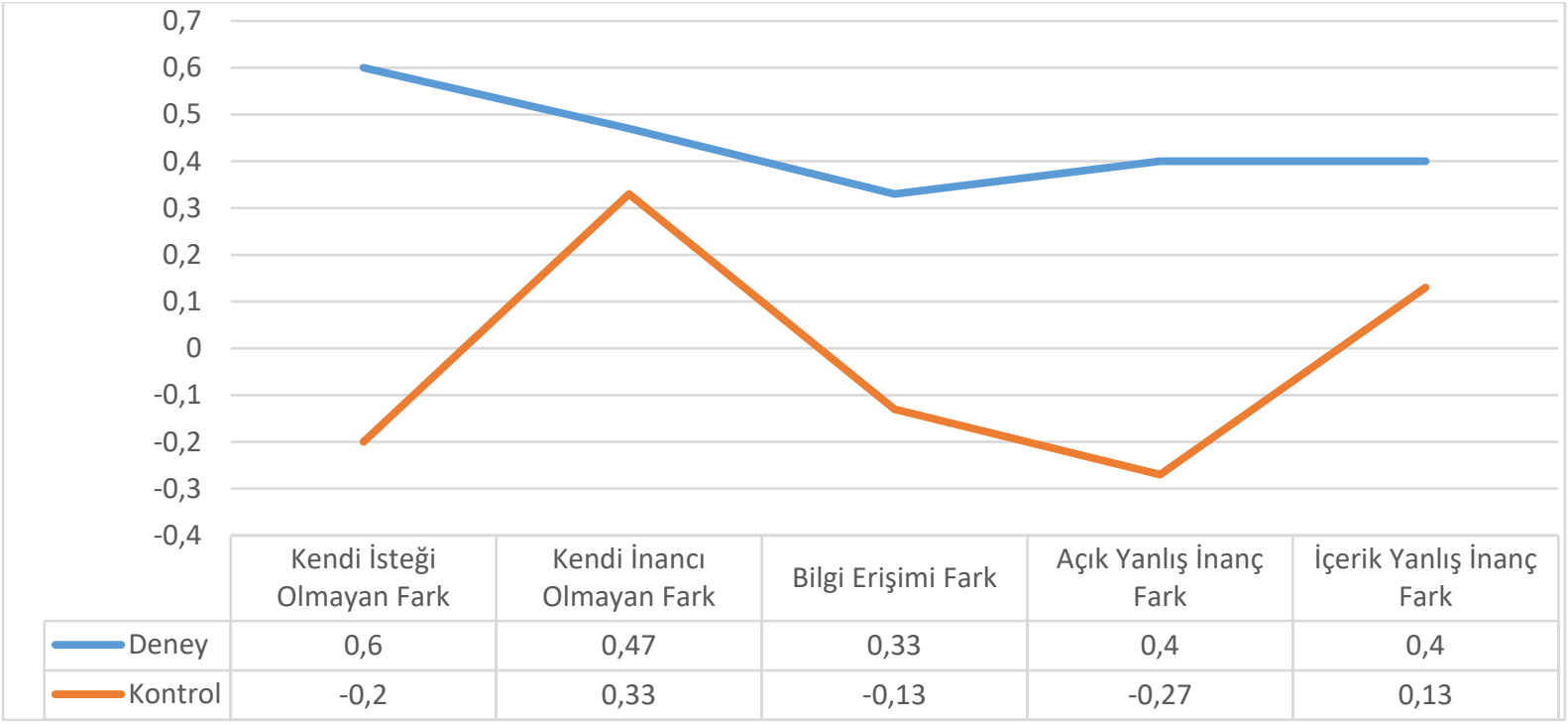

\section{Grafik 6. Gruplara Göre Zihin Kuramı Görevleri Değişsim Puanları Ortalamaları}

Grafik 6 incelendiğinde deney ve kontrol grubunun erişi puanları arası arasındaki farkın zihin kuramı görevlerinden kendi isteği olmayan, bilgi erişimi, açık yanlış inanç alt boyutlarında oldukça farklılaştığ görülmektedir. Aynı zamanda bu alt boyutlar için yapılan istatistiksel analiz sonucunda anlamlı farklılık bulunmuştur. En az fark kendi inancı olmayan boyutunda tespit edilirken, içerik yanlış inanç alt boyutu için de erişi puanları birbirine yakındır. Bu alt boyutların istatistiksel olarak anlamlı farklılık göstermediği de yapılan analiz sonucunda tespit edilmiştir.

\section{SONUÇ ve TARTIŞMA}

$\mathrm{Bu}$ araştırmanın genel amacı anasınıfına devam eden çocuklara, zihinsel düşünme becerilerinin kazandırılmasında yaratıcı drama çalışmalarının etkisini incelemektir. Araştırmada "zihin kuramı" gelişiminin 4-5-6 yaş olmasından kaynaklı olarak anasınıfına devam eden çocuklarla çalışılmıştır. Bu genel amaç doğrultusunda yaratıcı drama çalışmalarının zihin kuramında yer alan; kendi isteği olmayan, kendi inancı olmayan, bilgi erişimi, açık yanlış inanç ve içerik yanlış inanç alt boyutları üzerindeki etkisi araştırılmıştır.

Yaratıcı drama çalışmaları, çocukların zihin kuramı ölçeğindeki kendi isteği olmayan, bilgi erişimi, açık yanlış inanç olmak üzere üç alt boyutta ve zihin kuramı ölçeği toplam puanlarında farklılaşmaya neden olmaktadır. Aynı zamanda deney grubundaki çocukların zihin kuramı görevinin beş alt boyutu için (kendi isteği olmayan, kendi inancı olmayan, bilgi erişimi, açık yanlış inanç ve içerik yanlış inanç) ön test ve son test puanları ile son test ve kalıcılık test puanları anlamlı farklılık göstermektedir. Bu farklılık çocuklara uygulanan yaratıcı drama eğitiminin çocukların zihinsel becerilerinin gelişiminde etkili olduğunu göstermektedir. $\mathrm{Bu}$ 
bulgu Suddendorf ve Fletcher Flinn'in (1997; 1999) çalışmalarında ulaştıkları yaratıcılık ve zihin teorileri arasında anlamlı bir ilişki olduğu sonucunu destekler niteliktedir. Dietrich (2004) çalışmasında, yaratıcılık ve zihin kuramı üzerine yapılan araştırmaların her iki alana da katkı sağlayacağını belirtmiştir. Bu araştırmadaki bulguların da bu iki alana sınırlı düzeyde de olsa katk1 sağlayacağ1 düşünülmektedir.

Alan yazın incelendiğinde yaratıcı drama ve zihin kuramı arasındaki ilişkiyi araştıran bir çalışmaya rastlanmamıştır. Araştırma yaratıcı dram eğitimi içinde yer alan yaratıcılığı geliştiren etkinlikler olarak ele alındığında pek çok araştırma bu bulguyla paralellik gösteren sonuçlar ortaya koymuştur. Araştırmalarda yaratıcılık içeren ve farklı düşünme becerilerinin gelişimine yönelik uygulanan eğitimlerinin çocuklardaki problem çözme, eleştirel değerlendirme, soyut düşünme becerisi ve üstbiliş gibi pek çok üst düzey düşünme becerilerini geliştirerek, yapılan uygulamaların bu becerileri kullanmaya teşvik ettiği belirlenmiştir (Akkocaoğlu-Çayır, 2015; Cotton, 1991; Jenkins ve Lyle, 2010). Benzer şekilde Kontaş (2015), 5-11 yaş arası çocukların zihin teorisi ve yaratıcılık yetenekleri arasındaki ilişkiyi incelediği araştırmasında yaratıcılık ile zihin teorisinin tüm alt boyutları arasında anlamlı ve doğru yönde ilişki olduğu sonucuna ulaşmıştır.

Araştırmada deney grubu ön test ve son test puan ortalamaları kendi isteği olmayan görevine ilişkin zihin kuramı ölçeği toplam puanı arasında anlamlı bir fark bulunmuştur. Gözlemlenen bu farkın pozitif sıralar, yani son test puanı lehinde olduğu görülmektedir. Benzer şekilde aynı alt boyut için son test ve kalıcılık testi puanları arasında da oldukça az fark olduğu görülmektedir. Yapılan analiz sonucunda bu farklar anlamlı olarak farklı bulunmamıştır. $\mathrm{Bu}$ durum yaratıcı drama uygulaması sonucunda çocuklarda zihin kuramı görevlerinden kendi isteği olmayan alt boyutundan elde edilen gelişimin kalıcı olması ile açıklanabilir. Gruplar arası erişi puan ortalamalarının da anlamlı olduğu belirlenerek bulgu desteklenmiştir. Elde edilen sonuçlar yaratıcı drama uygulamalarının anasınıfı çocuklarında "farklı istekleri anlama" becerisi kazandırması açısından etkili olduğunu göstermektedir. 4 yaşından itibaren çocuklar başkalarının bir konu hakkında yanlış bir inanca ya da düşünceye sahip olabileceğini kavramaktadırlar (Santrock 2011, Perner, 1999). Çocuklara yönelik uygulanan eğitimlerin farklı istekleri anlama becerisini arttırdığı bu alanda yapılan farklı çalışmalarda da belirlenmiştir ( Appleton ve Reddy,1996; Benson, 2007; Santrock, 2011; Perner, 1999).

Yaratıcı drama uygulamalarının "farklı inançları anlama" becerisinde kendi inancı olmayan alt boyutunda deney grubu ön test ve son test puan ortalamaları arasındaki fark, istatistiksel olarak anlamlı bulunmuş, kontrol grubunda ise ön test ve son test puan ortalamalarının anlamsız 
olduğu saptanmıştır. Gruplar arası erişi puan ortalamalarının kendi inancı olmayan alt boyutları puanlarına ilişkin erişi puanları ortalamaları arasında anlamlı bir fark olmadığı görülmektedir. Kendi inancı olmayan alt boyutunda deney grubu ön test ve son test puan ortalamaları ile gruplar arası erişi puan ortalamaları arasındaki farklılı̆̆ın eğitim programında bu beceri geliştirmeye yönelik hazırlanmış olan çalışmaların etkin olmamasından dolayı kaynaklandığı düşünülebilir. Elde edilen sonuçlar yaratıcı drama çalışmalarının zihinsel düşünme becerisi kazandırmada zihin kuramı ölçeği "kendi inancı olmayan" alt boyutu açısından verilen eğitimin etkili olmadığını göstermektedir. Çocuklara uygulanacak olan eğitim programlarının devamlılığ1 sağlanarak bu alt boyut için performansın arttırılabileceği öngörülmektedir. Zihinsel kavramların çocuklara uygulanacak olan genel eğitim ile pozitif yönde gelişebileceğine dair bulgular literatürde yer almaktadır (Fisher ve Happe, 2005; Guajardo ve Watson, 2002; Ozonof ve Miller; 1995; Swettenham, 1996).

Zihinsel düşünme becerilerinin kazandırılmasında yaratıcı drama uygulamalarının etkinliğini ölçen ölçekte "bilgi erişimi” alt boyutu deney grubu ön test ve son test puan ortalamaları arasında anlamlı farklılaşma görülmüştür. Kontrol grubundaki çocukların bilgi erişimi, ön test ve son test puanları arasında anlamlı bir fark olmadığ belirlenmiştir. $\mathrm{Bu}$ sonuç kontrol grubundaki çocuklara eğitim uygulanmadığı için beklenen bir durumdur. Gruplar arası erişi puan ortalamalarında bilgi erişimi alt boyutunda, istatiksel olarak anlamlı bir fark olduğu belirlenmiştir. Elde edilen sonuçlar yaratıcı drama çalışmalarının zihinsel düşünme becerisi kazandırmada zihin kuramı ölçeği "bilgi erişimi" alt boyutu açısından verilen eğitimin etkili olduğunu göstermektedir. Astington ve Edward (2010), çalışmalarında zihin teorisinin bilgi erişimi alt boyutunda gelişim hızının, çocukların birden fazla kardeşe sahip olma, sembolik oyun oynama, yaşantısal deneyimleri hakkında konuşma ve hikâye kitabı okuma durumlarına karşın pozitif yönde bir farkındalık gösterdiğini belirlemiştir.

Yaratıcı drama uygulamalarının "açık yanlış inançları anlama” becerisinde açık yanlış inanç alt boyutunda deney grubu ön test ve son test puan ortalamaları, arasında fark anlamlı bulunmuş, kontrol grubunda ise ön test ve son test puan ortalamalarının anlamsız olduğu saptanmıştır. Gruplar arası erişi puan ortalamalarının da anlamlı olduğu belirlenerek bulgu desteklenmiştir. Elde edilen sonuçlar yaratıcı drama çalışmalarının zihinsel düşünme becerisi kazandırmada zihin kuramı ölçeği "açık yanlış inanç” alt boyutu açısından verilen eğitimin etkili olduğunu göstermektedir. Literatürde zihin teorisinin kazanım yaşı başlangıcının 4 yaş olduğu ve 6 yaşında bir çocuğun açık yanlış inançları anlayabilme becerisine sahip olması gerektiği belirtilmektedir. (Granti, 2004; Keçeli Kaysılı ve Acarlar, 2011; Lohmann ve Tomasello, 2003; 
Santrock 2011). Bu araştırmada anasınıfına devam eden çocukların genel bir çoğunluğunun zihinsel düşünme becerilerinden açık yanlış inançları anlama becerisinde literatürde beklenen performansı gösterdikleri belirlenerek bulgular desteklenmiştir.

Yaratıcı drama uygulamalarının "içerik yanlış inançları anlama" becerisinde içerik yanlış inanç alt boyutunda deney grubu ön test ve son test puan ortalamaları, arasında fark anlamlı bulunmuş, kontrol grubunda ise ön test ve son test puan ortalamalarının anlamsız olduğu saptanmıştır. Gruplar arası erişi puan ortalamalarında ise anlamlı bir fark olmadığı belirlenmiştir. Bu sonuç eğitim yapıldıktan sonra deney ve kontrol grubundaki çocukların zihin kuramı ölçeği içerik yanlış inanç alt boyutundaki özelliklerinin değişmediğini göstermektedir. Elde edilen sonuçlar yaratıcı drama çalışmalarının zihinsel düşünme becerisi kazandırmada zihin kuramı ölçeği "açık yanlış inanç” alt boyutu açısından verilen eğitimin etkili olmadığını göstermektedir. Gözün-Kahraman (2012), zihin kuramına dayalı eğitim programının 48-60 aylık çocukların bilişsel bakış açısı becerileri ve prososyal davranışları üzerine etkisini incelediği araştırmasında deney ve kontrol grubundaki çocukların beklenmeyen içerik görevine ilişkin bulgularında da çalışmanın bulguları ile aynı sonuca ulaşarak grup puanlarında anlamlı bir farklılık belirtmemiştir. Literatürde çocukların 4 yaşından itibaren farklı insanların yanlış inançlarını doğru tahmin edebileceklerine dair bilgiler yer almaktadır (Gopnik ve Astington, 1988; Perner ve diğerleri, 1987). Bu alt boyut için oluşan farklılığın kardeş sayısı, yaş ya da kültürel faktörlerden kaynaklanabileceği düşünülmektedir.

$\mathrm{Bu}$ çalışma, anasınıfına devam eden çocukların zihinsel düşünme becerilerinin bu konuda uygulanacak yaratıcı drama eğitim programı ile desteklenebileceğini göstermesi açısından önemlidir. Ayrıca bu araştırma, yaratıcı drama çalışmaları uygulanarak verilen eğitimin zihinsel düşünme becerilerini geliştirdiğini de göstermektedir. Zihin kuramı yeteneği başarılı sosyal iletişim ve etkileşim için çok önemlidir. Yaratıcı drama çalışmalarının da içinde barındırdığı yaparak yaşayarak öğrenme etkisi ile sosyalleşmeye katkı sağladığı bilinmektedir. Ülkemizde zihin kuramı yeteneği konusunda yapılan çalışmaların çok az olduğu görülmektedir. Sosyal çevre ile iletişim açısından önem taşıyan zihinsel düşünme becerilerinin okul öncesi dönem çocuklarının gelişimindeki önemini kavrayarak alana katkı sağlayabilmek için özellikle eğitim alanında disiplinlerarası yapılacak çalışmalara ihtiyaç duyulmaktadır.

\section{KAYNAKÇA}

Balc1. A. (2007). Sosyal bilimlerde araştırma: Yöntem, 1.5nik ve ilkeler. Ankara: Pegema Adıgüzel, Ö. (2012). Eğitimde yaratıcı drama (İkinci baskı). Ankara: Naturel Yayıncılık, s.11437. 
Akkocaoğlu-Çayır, N. (2015). Çocuklar İçin Felsefe Eğitimi üzerine nitel bir araştırma. Yayınlanmamış doktora tezi. Hacettepe Üniversitesi, Ankara.

Appleton, M., \& Reddy, V. (1996). Teaching 3-year-olds to pass false-belief tests: A conversational approach. Social Development, 5, 275 - 291.

Aslan,E. (2001). “Torrance Yaratıcı Düşünce Testi” Türkçe versiyonu. Marmara Üniversitesi Atatürk Ĕ̆itim Fakültesi Eğitim Bilimleri Dergisi, 14, 19-40.

Astington, J. W., ve. Edward, M. J. (2010). The development of theory of mind in early childhood. encyclopedia on early childhood development. Centre of Excellence for Early Childhood Development; Web, http://www.child-encyclopedia.com Gxp. pdf. adresinden 17.06.2017'de alınmıştır.

Baron-Cohen, S., Leslie, M.A. and Frith, U. (1985). Does the autistic child have a "theory of mind? ”.MRC Cognitive Development Unit, London.Cognitive, 21, 37-46.

Baron-Cohen, S. (2000). Theory of mind and autism a fifteen year rewiew. S. Baron-Cohen, $\mathrm{H}$. Tager-Flusberg., ve D. Cohen (Eds.), Understanding other minds: Perspectives from developmental cognitive neuroscience. (Second edition) (p. 3-20). New York: Oxfo.

Benson, J.E. (2007). Executive Functioning And Theory Of Mind Development: A Training Study. Unpublished master's thesis. Queen's University, Kingston, Ontario, Canada.

Cotton, K. (1991). Teaching thinking skills. School improvement research series. http://www.nwrel.org/scpd/sirs/6/cul1.html. Erişim tarihi: 09.10.2017.

Dietrich, A. (2004). The cognitive neuroscience of creativity. Psychon. Bull. Rev. 11, 10111026.

Ertuğrul, Z. (2011). Zihin Kuramı, Dil Ve Çalışma Belleği Arasındaki Gelişimsel Bağlantılar, Yüksek Lisans Tezi, İstanbul Üniversitesi, Sosyal Bilimler Enstitüsü, Psikoloji Anabilim Dal1, s: 4-16.

Fisher, N. and Happé, F. (2005). A training study of theory of mind and executive function in children with autistic spectrum disorders. Journal of Autism and Developmental Disorders, 35, 757-771.

Flavell, J. H., and Miller, P. H. (1998). Social cognition. In D. Kuhn and R. Siegler (Eds.), Handbook of child psychology: Vol. 2: Cognition, perception, and language (pp. 851 898). New York: Wiley.

Gopnik, A, Astington, J W. (1988). "Children's understanding of representational change and its relation to the understanding of false belief and the appearance-reality distinction" Child Development, 59(1), 26-37.

Gözün-Kahraman, Ö. (2012). Zihin kuramına dayalı eğitim programının 48-72 aylık çocukların bilişsel bakış açısı becerileri ve prososyal davranışları üzerindeki etkisinin incelenmesi. Yayınlanmamış doktora tezi. Gazi Üniversitesi, Ankara.

Granti, T. (2004). The ralationship between metacognitive vocabulary and theory of mind develeopment. Boğaziçi Universty Institute for Graduate Studies in Social Science Master of Arts in Psychology: İstanbul.

Guajardo, N. R., and Watson, A.C. (2002). Narrative discourse and theory of mind development. The Journal of Genetic Psychology, 163( 3), 305-325. 
Jenkins, P. \& Lyle, S. (2010). Enacting dialogue: The impact of promoting philosophy for children on the literate thinking of identified poor readers, aged. Language and Education, 24(6), 459-472.

Karasar, N. (2014). Bilimsel araştırma yöntemi (27. bs.). Ankara: Nobel Yayınevi s: 92-102.

Keçeli Kaysılı, B. and Acarlar, F. (2011). Zihin kuramının 3-5 yaşları arasındaki çocuklarda gelişiminin yanlış inanç performansına göre incelenmesi. Kuram ve Uygulamada Ĕgitim Bilimleri, 11(4), 1809-1826.

Keskin, A. (2009). İlköğretim düşünme eğitimi dersi (6.,7., ve 8. Sınıf) öğretim programının değerlendirilmesi. Yayınlanmamış yüksek lisans tezi. Mustafa Kemal Üniversitesi, Hatay.

Kontaş T. (2015). 5-11 Yaş Arası Çocukların Zihin Teorisi Ve Yaratıcılık Yetenekleri Arasındaki İlişkinin Çeşitli Değişkenler Açısından İncelenmesi. Yüksek Lisans Tezi, Karadeniz Teknik Üniversitesi Eğitim Bilimleri Enstitüsü İlköğretim Anabilim Dalı.

Milli Eğitim Bakanlığı (2013). Okul Öncesi Eğitimi Genel Müdürlüğü Okul Öncesi Eğitim Programı (36-72 aylık çocuklar için). T. Gürkan ve G. Haktanır (Ed.) Ankara: MEB Yayınları.

Leslie, A.M., (1987), Presente and representation: The Origins of "Theory of Mind.", Psychological Review, 94 (4), 412-426.

Lohmann, H., \& Tomasello, M. (2003). The role of language in the development of false-belief understanding: A training study. Child Development, 74, $1130-1144$.

Ozonoff, S. and Miller, J.N. (1995). Teaching theory of mind: A new approach to social skills training for individuals with autism. Journal of Autism and Developmental Disorders, $25,415-433$.

Palut, B. (2006). Farklı düşünme biçimleri ve ögrrenme. Ayla Oktay, Özgül Polat Unutkan (Ed.), İlköğretim Çağına Genel Bir Bakış içinde (101-118). İstanbul: Morpa Kültür Yayınları.

Perner, J., Leekam, R. and Wimmer, H. (1987). Three year olds difficulty with false belief: The case for a conceptual deficit. British Journal of Developmental of Psychology, 5, 125 137.

Perner, J.,(1999). Theory of Mind. Draft of Chapter to Appear in: In M. Bennett (Ed.). Developmental Psychology: Achievements \& Prospects. Hove, East Sussex: Psychology Press.

Premack, D., Woodruff, G. (1978). Does the chimpanzee have a theory of mind? Behav and Brain Sci 1: 515-526.

Sağlam, T. (2003). Dramatik Eğitim Amaç Mı Araç Mı?. Tiyatro Araştırmaları Dergisi, Sayl:17, s.4-11.

Santrock, J.W. (2011). Yaşam boyu gelişim, Çev. Editörü; Galip Yüksel(13. Bask1). Ankara: Nobel Akademik Yayıncılık. S.36.

Schlinger, H.D. (2009). Theory of mind: An overview and behavioral perspective. The Psychological Record, 59, 435-448.

Suddenford,T., Fletcher-Flinn, C. M. (1997). Theory of mind and origin of divergent thinking. Journal of Creative Behavior. 31(3), 169-179.

Suddendorf T.,ve Fletcher-Flinn, C. M. (1999). Children's divergent thinking improves when they understand false beliefs. Creativity Research Journal, 12(2), 115-128. 
Swettenham, J. (1996). Can children with autism be taught to understand false belief using computers? Journal of Child Psychology and Psychiatry, 37, 157-165.

Wellman, H.M. and Bartsch, K. (1994). Before belief: Children's early psychological theory. In C. Lewis \& P. Mitchell (Eds.), Children's early understanding of mind: Origins and development (pp. 331-354).

Wellman, H. M., \& Estes, D. (1986). Early understanding of mental entities: a reexamination of childhood realism. Child Development, 57, 910-923.

Wellman, H.M. and Liu, D. (2004). Scaling of theory-of-mind tasks. Child Development, 75(2), $523-541$.

Üstündağ, T. (1994). Günümüz eğitiminde dramanın yeri. Yaşadıkça Eğitim Dergisi, (37), s.710. 